\title{
In Memoriam: Herbert E. Wright, Jr., 1917-2015
}

\author{
Cathy Whitlock $^{\mathrm{a}, *}$, Julie K. Stein ${ }^{\mathrm{b}}$, Sherilyn Fritz ${ }^{\mathrm{c}}$ \\ a Department of Earth Sciences and Montana Institute on Ecosystems, Montana State University, Bozeman, MT 59717, USA \\ b Burke Museum of Natural History and Culture, University of Washington, Seattle, WA 98195, USA \\ c Department of Earth and Atmospheric Sciences and School of Biological Sciences, University of Nebraska-Lincoln, Lincoln, NE 68588, USA
}

\section{A R T I C L E I N F O}

\section{Article history:}

Received 1 December 2015

Available online 8 January 2016

\section{Keywords:}

Herbert E. Wright Jr

Quaternary paleoecology

Paleoclimatology

Biogeography

Archaeology

Professor Herbert E. Wright passed away on November 12, 2015 in his $98^{\text {th }}$ year. His passing leaves many in Quaternary community reflecting on his enormous contributions to the discipline, as well as the many ways in which he touched our lives. Herb's legacy, writ large, is evidenced by decades of scholarly contributions to the fields of glacial geology, geomorphology, paleoecology, paleolimnology, paleoclimatology, and archaeology. During the course of his career, he authored and co-authored over 250 scientific publications and coedited 16 influential volumes on the Quaternary.

Herb was a Regents Professor of Geology, Ecology, and Botany at the University of Minnesota, where he joined the faculty in 1947. He earned his Masters and PhD in geology from Harvard $(1941,1943)$ and never failed to acknowledge the generosity and guidance of his advisor, Kirk Bryan. Herb attributed his love of landscapes and their evolution to his time as a graduate student exploring the remote parts of the Chuska Mountains of New Mexico.

Herb helped establish Quaternary studies as a viable and important discipline in North American universities, and he was a strong advocate for using science to advance environmental conservation. He supervised more than 70 Masters and Ph.D. students at the University of Minnesota and mentored students with Quaternary interests from other institutions. Herb also supported several post-doctoral researchers and contributed to their successful professional development. If asked, a large sector of the Quaternary research community in the USA and around

\footnotetext{
* Corresponding author.

E-mail addresses: whitlock@montana.edu (C. Whitlock), jkstein@uw.edu (J.K. Stein), sfritz2@unl.edu (S. Fritz).
}

the world would credit Herb with influencing their career trajectory. Herb was clearly one of those leaders who led from behind: he was soft-spoken and a good listener, an observant tireless field worker, a ferocious editor, and a patient supportive mentor. He encouraged students to utilize technology as tools but not to shy away from direct observation, both in the field and lab, in their search for understanding. He often took a backseat, playing the role of field assistant, wise counsel, and grand synthesizer. His strength was to recognize good ideas, seize on interdisciplinary connections overlooked by others, and ensure that discoveries made their way to publication (Figure 1).

Herb established the Limnological Research Center (LRC) in 1959, with a grant from the Hill Family Foundation, and remained Director until his retirement in 1990. The early days of the LRC must have been a lively time. Support from the newly established National Science Foundation was assured, radiocarbon dating was a new tool being applied to a variety of research questions, and the opportunity for fundamental discoveries in environmental history must have seemed limitless. A strategy of Herb was to invite the foremost scientists from European laboratories to spend extended and repeated visits at the LRC. These researchers, with Herb's support, initiated some of the first "modern" paleoenvironmental studies in North America, and in turn, they trained and inspired new American and European researchers. For several decades, Herb also sponsored an evening seminar at his home, and countless scientists

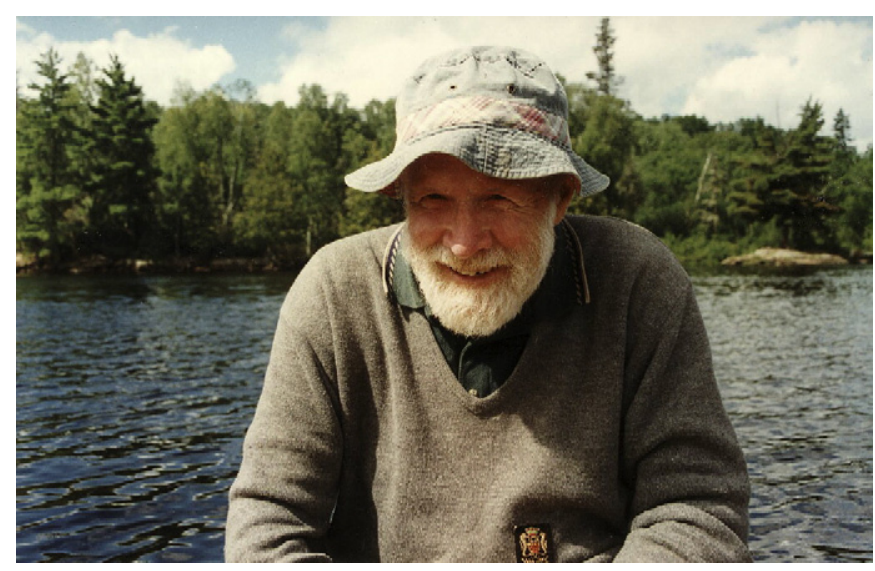

Figure 1. Herb Wright in the Boundary Waters Canoe Area, Minnesota, 2004 (photo by Brigitta Ammann). 
from across the world participated in this intimate venue for discussing science and exchanging ideas.

Some of Herb's many scientific accomplishments include:

- Mapped the sequence of advances and retreats of several lobes of the Laurentide ice sheet and described their role in creating lakes and wetlands. This research also documented periods of erosion and deposition in the Minnesota and Mississippi River valleys as a result of glacial recession.

- Summarized the postglacial vegetation history of Minnesota based on pollen and plant macrofossil records. These records traced the transition from tundra to spruce parkland and then pine forest, that led to the creation of present-day boreal forest, deciduous woodland, and prairie-foundational work for many disciplines.

- Spent several years working on peatlands in northern Minnesota, including understanding their origins, complex patterns, vegetation, and hydrology and later carried out comparative studies in Sweden, Labrador, and Ireland.

- Collaborated with archaeologists who were mapping settlement patterns and excavating early villages in the Near East and used pollen evidence to show that plant domestication by Neolithic farmers began during the climate transition at the end of the last ice age.

- Championed studies of fire history and the importance of fire history for fire management. This work, which started in the Boundary Waters Canoe Area, led to new fire history research in the United States and around the world.

- Studied the Quaternary history of the Peruvian Andes, the Rocky Mountains, and the Yukon through field mapping and lake studies.

- Provided an early home for North American paleolimnology, sponsoring studies on the patterns of lake ontogeny following glacial retreat, the impacts of human disturbance on lake ecosystems, and past lake-level change.

- Collaborated with scientists from Eastern Europe at the end of the Cold War to study regional vegetation history and climate change.

- Co- founded the Cooperative Holocene Mapping Project (COHMAP), which brought together an interdisciplinary international team of scholars in the 1980s and 1990s to understand the climate and environmental changes of the last 21,000 years. COHMAP remains one of the most successful and enduring examples of collaboration in Quaternary sciences.

- Developed the square-rod Livingston piston corer, which is still made and sold in Minnesota.

Herb's distinguished career achievements are recognized by many awards and honors. He received a Guggenheim Fellowship (19541955) and honorary degrees from Trinity College Dublin (1966) and Lund University (1987). He was named Regents Professor at the University of Minnesota (1974) and elected to the National Academy of Sciences (1977). He received the Pomerance Award from the Archaeological Institute of America (1985), the Distinguished Career Award from the Quaternary Geology and Geomorphology Division of the Geological Society of America (1992), the Fryxell Award for geoarchaeology from the Society of American Archaeology (1993), a Distinguished Career Award from the American Quaternary Association (1996), and a Lifetime Achievement Award from the International Paleolimnology Association (2009).

This professional recognition is only part of the story. Many of Herb's former students are now prominent scientists in their own right, located at academic institutions and research centers around the world. Colleagues and former students, whenever together, are quick to lapse into "Herb stories", reminiscing about the character-building adventures that inevitably occurred in the field with Herb. His ability to withstand the most miserable, life-threatening, and often reckless expeditions, even into his last decade, only adds to the shared bond and sense of pride that former students and friends feel when thinking about Herb Wright. The Quaternary research community will deeply miss this amazing scientist, mentor, and friend.
Selected papers and edited and co-edited volumes by Herb Wright:

- Wright, H.E., Jr., Frey, D.G. (Eds.), 1965. The Quaternary of the United States. Princeton University Press.

- Wright, H.E., Jr., 1967. A square-rod piston sampler for lake sediments. Journal of Sedimentary Petrology 37, 975-976.

- Cushing, E.J., Wright, H.E., Jr. (Eds.), 1967. Quaternary Paleoecology. Yale University Press, New Haven.

- Martin, P.S., Wright, H.E., Jr. (Eds.), 1967. Pleistocene Extinctions. Yale University Press, New Haven.

- Wright, H.E. Jr., 1968. The natural environment of early food production north of Mesopotamia. Science 161, 334-339.

- Wright, H.E., 1972. Quaternary history of Minnesota. In: Sims, P.K., Morey, G.B., (Eds.), Geology of Minnesota. Minnesota Geological Survey, St. Paul, pp. 515-546.

- Wright, H.E., Jr., 1974. Landscape development, forest fires, and wilderness management. Science 186, 487-495.

- Wright, H.E., Jr., 1976. The dynamic nature of Holocene vegetation: a problem in paleoclimatology, biogeography, and stratigraphic nomenclature. Quaternary Research 6, 581-596.

- Wright, H.E., Jr., 1976. The environmental setting for plant domestication in the Near East. Science 194, 385-398.

- Wright, H.E., Jr., 1977. Quaternary vegetation-some comparisons between Europe and America. Annual Reviews of Earth and Planetary Science 5, 123-158.

- Wright, H.E., Jr., 1981. Vegetation east of the Rocky Mountains 18,000 years ago. Quaternary Research 15, 113-125.

- Wright, H.E., Jr., 1983. Late-Pleistocene glaciation and climate around the Junin Plain, central Peruvian highlands. Geografiska Annaler 65A, 35-43.

- Wright, H.E., Jr. (Ed.), 1983. Late-Quaternary Environments of the United States, vol. 2. University of Minnesota Press, Minneapolis.

- Wright, H.E., Jr., 1984. Sensitivity and response time of natural systems to climatic change in the last Quaternary. Quaternary Science Reviews 3, 91-133.

- Wright, H.E., Jr., Barnosky, C.W. (Eds), 1984. Late-Quaternary Environments of the Soviet Union. University of Minnesota Press, Minneapolis.

- Engstrom, D.R., Wright Jr, H.E., Jr., 1984. Chemical stratigraphy of lake sediments as a record of environmental change. In: Haworth, E.Y., Lund, J.W.G., (Eds.), Lake Sediments and Environmental History. University of Minnesota Press, Minneapolis, pp. 11-67.

- Kutzbach, J.E., Wright Jr., H.E., Jr., 1985. Simulation of the climate of 18,000 years BP: Results for the North American/North Atlantic/European sector and comparison with the geologic record of North America. Quaternary Science Reviews 4, 147-187.

- Ruddiman, W.F., Wright, H.E., Jr. (Eds.), 1987. North America and Adjacent Oceans during the Last Deglaciation. The Geology of North America, volume K-3. The Geological Society of America, Boulder.

- Wright, H.E., Jr., 1989. The amphi-Atlantic distribution of the Younger Dryas paleoclimatic osciallation. Quaternary Science Reviews 8, 295-306.

- Wright, H.E., Jr., 1992. Patterns of Holocene climatic change in the midwestern United States. Quaternary Research 38, 129-134.

- Wright, H.E., Jr., Coffin, B.A., Aaseng, N.E. (Eds.), 1992. Patterned Peatlands of Northern Minnesota. University of Minnesota Press, Minneapolis.

- Wright, H.E., Jr., Kutzbach, J.E., T. Webb III, Ruddiman, W.F., Street Perrott, F.A., Bartlein, P.J. (Eds.), 1993. Global Climates since the Last Glacial Maximum. University of Minnesota Press, Minneapolis.

- Berglund, B.E., Birks, H.J.B., Ralska-Jasiewiczowa, Wright, H.E. (Eds.), 1996. Palaeoecological Events during the Last 15000 Years: Regional Syntheses of Palaeoecological Studies of Lakes and Mires of Europe. John Wiley \& Sons, Chichester. 
- Yu, Z., Wright Jr., H.E., Jr., 2001. Response of interior North America to abrupt climate oscillations in the North Atlantic region during the last deglaciation. Earth Science Reviews 52, 333-369.

- Ralska-Jasiewiczowa, M., Latalowa, M., Wasylikowa, K., Tobolski, K., Madeyska, E., Wright, H.E., Turner, C. (Eds.), 2004. Late Glacial and Holocene History of Vegetation in Poland based on Isopollen Maps. W. Szafer Institute of Botany, Polish Academy of Sciences, Krakow.
- Wright, H.E., 2005. Contrasts in the Quaternary of mid-North America and mid-Eurasia: notes of Quaternary landscapes of western Siberia. Journal of Quaternary Science 20, 813-819.

- Wright, H.E., Jr., Thorpe, J., 2014. Climatic change and the origin of agriculture in the Near East. In: Mackay A.W., Battarbee R.W., Birks H.J.B., Oldfield, F., (Eds.), Global Change in the Holocene. Hodder Arnold, London, pp. 49-62. 